AVALIAÇÃO EM SAÚDE. Dos modelos conceituais à prática na análise da implantação de programas. Zulmira de Araújo Hartz (organizadora). Rio de J aneiro: Editora Fiocruz, 1997. 131 pp. ISBN : 85-85676-36-1

O campo da avaliação em saúde no Brasil, ainda pouco formalizado na sua prática científica e técnica, vive atualmente um momento de crescente visibilidade e expectativas internas e externas. De um lado, trata-se do reflexo da sua maior presença no cenário internacional da Saúde Pública/Saúde Coletiva e, por outro, a presença de conjunturas econômicas, políticas e de organização do sistema de saúde que colocam a necessidade da presença também de conhecimentos mais especificados relativos às suas práticas, por parte dos profissionais de saúde, como parte do processo de implementação das políticas de saúde. Passa a ser mais freqüente o diálogo entre o conhecimento que a Saúde Coletiva no Brasil produziu sobre a determinação social dos processos de saúde/ doença e as políticas e práticas de saúde e uma literatura internacional, predominantemente produzida nos países desenvolvidos de língua inglesa, sobre formas de reconhecimento de processos e tecnologias em saúde que têm por objetivo a elaboração de um juízo de valor sobre os mesmos, e que sejam capazes de contribuir para os processos de tomada de decisão política e técnica. Este livro, organizado por Zulmira de Araújo Hartz, pesquisadora da Escola Nacional de Saúde Pública (Ensp) da Fiocruz e com reconhecida especialização em avaliação em saúde, ao propiciar o acesso a textos nucleares para a área e promover o diálogo com experiências nacionais, deverá contribuir de forma importante para a ampliação do conhecimento e da prática de avaliação em saúde no nosso país.

O Prefácio, escrito por Lilia B. Schraiber, através do encadeamento das questões formuladas aponta para a riqueza dos diálogos a serem desenvolvidos entre uma produção teórica já consolidada da Saúde Coletiva relativa às alternativas historicamente construídas de "alianças entre a ciência, a técnica e a política" no campo da saúde, e a área de avaliação em saúde, que toma essa perspectiva como um ponto de partida quase paradigmático para a conformação da sua prática.

O Capítulo 1, elaborado por Zulmira de Araujo Hartz, intitulado "Explorando novos caminhos na pesquisa avaliativa das ações de saúde", discute alguns dos conceitos teóricos básicos para a avaliação em saúde, no que diz respeito às possibilidades de reconhecimento e intervenção sobre o real, apontando a teoria da complexidade e, particularmente, a produção de Morin, como uma referência importante a ser explorada.

Os Capítulos 2 e 3 são versões adaptadas de artigos seminais de autores consagrados da Escola de
Planejamento da Universidade de Montréal, do Canadá. No Capítulo 2, "A avaliação na área da saúde: conceitos e métodos", André-Pierre ContandriopouIos, François Champagne, Jean-Louis Denis e Raynald Pineault apresentam uma proposta de tipologia das principais linhas de avaliação em saúde, divididas em Avaliação Normativa e Pesquisa Avaliativa e seus subtipos ou perspectivas de análise. Na Pesquisa Avaliativa são identificados seis tipos de análise: estratégica, da intervenção, da produtividade, dos efeitos do rendimento e da implantação. Esta última, dado o seu potencial de aplicação na realidade brasileira, é apresentada de forma detalhada por Jean-Louis Denis e François Champagne no Capítulo 3. São ali discutidas as principais questões relativas à validade externa da avaliação da implantação, seus componentes, modelos de análise de contexto e apresentados alguns exemplos de avaliações realizadas.

No Capítulo 4, para completar o movimento proposto no subtítulo do livro, "dos modelos conceituais à prática na análise da implantação de programas", Zulmira de Araújo Hartz, François Champagne, André-Pierre Contandriopoulos e Maria do Carmo Leal apresentam a "Avaliação do Programa Materno-Infantil: análise de implantação em sistemas locais de saúde no Nordeste do Brasil". Apoiado nos resultados obtidos da pesquisa de Z. Hartz para a Tese de Doutoramento defendida em 1993 na Universidade de Montréal, na qual foi feita uma avaliação da implantação do programa de atenção materno-infantil em dois sistemas locais de saúde, o texto apresenta de forma didática as etapas necessárias ao desenvolvimento deste tipo de avaliação, com especial atenção para a seleção dos indicadores, demonstrando a viabilidade e utilidade desta análise como instrumento para o planejamento e gestão dos programas e serviços de saúde.

Em conclusão, trata-se de um livro que deverá ter um grande impacto em todos os profissionais de saúde, ao apresentar alternativas para as formas de pensar as suas práticas e as possibilidades de transformação das mesmas, em textos de nível teórico elevado e linguagem clara.

Hillegonda Maria Dutilh Novaes

Departamento de Medicina Preventiva

Faculdade de Medicina

Universidade de São Paulo

São Paulo, SP 
Conocimientos Actuales sobre Nutrición. Publicação Científica N o. 565. Ekhard, E. Ziegler \& L.J . Filer, J r. (ed.). Washington D.C.: Organización Panamericana de la Salud e Instituto Internacional de Ciencias de la Vida, 7ạ ed., 1997. 731 pp.

Resenhar a sétima edição em espanhol da Publicação Científica "Conocimientos Actuales sobre Nutrición" foi tarefa que exigiu, além de inúmeras horas de leituras, um cuidado especial, qual seja, o de não se perder nos meandros de tanta informação científica ao longo de seus 64 capítulos.

Publicada pela primeira vez em 1953, “Conocimientos Actuales sobre Nutrición" é hoje, indubitavelmente, um dos tratados mais consultados na área de Nutrição, na medida que passou a constituir-se em um texto de referência obrigatório para todos os especialistas e estudantes de Nutrição.

Por tratar-se de publicação que reflete o grande dinamismo do campo, assim como por expor de forma clara e profunda temas recentes sobre o assunto, "Conocimientos Actuales sobre Nutrición" é imprescindível para consulta em aulas, laboratórios e clínicas em todo o mundo.

Nesta sétima edição, 4 capítulos foram subtraídos, assim como em relação à edição anterior, publicada em 1991, outros 13 foram adicionados, o que objetivou incluir as informações mais atualizadas e mostrar as fronteiras que permeiam o campo das ciências da Nutrição no final deste milênio.

Os 64 capítulos podem em linhas gerais ser divididos em 8 grandes grupos. Estes grupos temáticos, por sua vez, incluem textos sobre: I. Energia; II. Macronutrientes; III. Vitaminas lipo e hidrosolúveis; IV. Macro e micro minerais; $V$. Necessidades fisiológicas especiais; VI. Nutrição e doenças crônicas; VII. Estado nutricional eVIII. Temas especiais ou em evolução.

Da totalidade dos capítulos da obra, cerca de $20 \%$ referem-se à discussão sobre vitaminas $(A, D, E, K, C$, Tiamína, Riboflavina, Vitamina B-6, Niacina, Vitamina B-12, Ácido Fólico, Biotina e Ácido Pantoténico), outros vinte sobre oligoelementos (Cálcio e Fósforo, Magnésio, Sódio, Potássio, Ferro, Zinco, Cobre, Selênio, Flúor, Manganês e Cromo) e um décimo sobre morbidade associada (Arteriosclerose, Hipertensão, Diabetes Mellitus, Osteoporose e Osteomalácia, Doença Renal, Hepática, Câncer e Enfermidades gastrointestinais).

O número de referências bibliográficas é extremamente elevado (mais de $5 \mathrm{mil}$ ), bem como, em menor escala, o de tabelas e gráficos. A obra consta ainda com um índice de autores, ( 82 no total) e índice de assuntos.

Contrastando esta edição com a anterior, entre os 13 capítulos acrescidos, destacam-se, entre outros, 3 novos capítulos sobre doenças crônicas e nutrição (Arteriosclerose, Enfermidades gastrointestinais, e Câncer e dieta), um sobre Epidemiologia Nutricional e outros 5 sobre alguns temas ainda em franca evolução (Substituto dos macronutrientes, Antioxidantes, Reações adversas aos alimentos, Situação dos nutrientes e função do sistema nervoso central e Erros inatos do metabolismo).

No conjunto, os capítulos são extremamente atuais e espelham o crescimento da base científica das aplicações da Ciência da Nutrição a uma vasta gama de disciplinas relacionadas. "Conocimientos Actuales sobre Nutrición" é uma obra de cunho científico das mais completas sobre as Ciências da Nutrição, beneficiando um extraordinário número de alunos, especialistas, investigadores e profissionais que atuam na área, o que faz com que a mesma constitua-se em leitura obrigatória, para os iniciados ou não ao tema, assim como em acervo essencial de bibliotecas de universidades e centros de pesquisa.

\section{Gilberto Kac}

Universidade Federal do Rio de Janeiro

Instituto de Nutrição Josué de Castro

Departamento de Nutrição Social e Aplicada

Rio de Janeiro, RJ

DO CONTÁGIO À TRANSMISSÃO: CIÊNCIA E CULTURA NA GÊNESE DO CONHECIMENTO EPIDEM IO LÓ GICO. Dina Czeresnia, Rio de J aneiro: Editora Fiocruz, 1997. 123 pp.

ISBN 85-85676-32-9

A obra é constituída de cinco capítulos, além de introdução e conclusão. No Capítulo 1, a autora trabaIha com a formação do conceito de organismo, tendo em vista que da representação do corpo de um organismo vivo e de suas relações com o meio externo é que se definirão conceitos como os de doença, transmissão etc. No Capítulo 2, discute os conceitos de contágio e constituição epidêmica. Apesar da crença generalizada, estes conceitos não se sucederam linearmente na história. Eles se constituíram de formas diferentes de compreensão de um dos mais importantes fenômenos vividos pelas sociedades medievais - as epidemias. Para se ter idéia da importância da ocorrência de grandes e devastadoras epidemias que, com freqüência, assolavam as populações medievais, alguns autores destacam o papel das mesmas como um dos principais responsáveis pela conformação das idéias neste período histórico. O conceito de constituição epidêmica, construído por Sydenham (1624-1689) e afinado com idéias dos miasmas, então dominantes, precede o surgimento da teoria contagionista elaborada por Fracastoro no século anterior. Uma das conseqüências mais importantes e concretas destas divergências ocorre no momento da organização das práticas sanitárias para a prevenção e combate das epidemias, que serão definidas pelo Estado interventor que se conformará nos séculos subseqüentes (XVIII eXIX). Enquanto os con- 
tagionistas representavam o Estado na sua forma conservadora e burocrática, os constitucionistas colocam seus esforços nas melhorias ambientais e nas transformações sociais do meio. No Capítulo 3, a autora aprofunda-se no estudo da transmissão. Aqui desmistifica um outro dogma, ao concluir que o conceito de transmissão não é simplesmente a vitória da teoria do contágio, e sim conseqüência do desenvolvimento científico no campo da morfologia e da patologia humana, dos quais os anticontagionistas também participaram. Porém, ao mesmo tempo, o avanço científico fundamenta a negação das experiências de construção de uma visão da doença como o resultado da relação do corpo com o seu ambiente externo e, em uma perspectiva reducionista, passa a compreendê-la como um processo restrito ao meio interno, portanto confinada ao interior do corpo. Assim, enquanto no plano da ciência não houve vitoriosos ou derrotados, no plano das idéias é diferente - vence uma forma de ver e entender o mundo. No Capítulo 4, este debate é transferido para um outro cenário - o momento da constituição da epidemiologia como campo científico e disciplina acadêmica, nas primeiras décadas do presente século. A noção de constituição epidêmica continua no discurso de alguns autores, agora um discurso dominado e não mais dominante, que tem que ser reconstruído ao sofrer a influência de novos conceitos como imunidade, susceptibilidade e resistência, além do nascente, porém fundamental, conceito de risco. No Capítulo 5, o debate expande-se sobre o conceito de transmissão e utiliza-o na compreensão de um fenômeno concreto - $a$ atual epidemia de Aids.

Este livro, resultante da tese de doutoramento da autora, teve o seu lançamento em um momento dos mais oportunos, pois contribui em pelo menos duas importantes direções. Primeiro, para o crescente debate intelectual que acontece com base em questionamentos sobre as estratégias dominantes adotadas na produção do conhecimento epidemiológico; segundo, para a reflexão daqueles que se posicionam em confronto com as novas formas de biologismo centradas no determinismo genético da vida. Este dois debates estão interligados na história do conhecimento das doenças infecciosas e de suas epidemias. É com maestria, segurança e vitalidade intelectual que a autora nos conduz nesse enredo que, em alguns momentos, só poderá vir a ser entendido se retomarmos períodos e acontecimentos remotos. Entretanto, os aspectos ideológicos e culturais que são fundantes e circundam o conhecimento científico têm que ser compreendidos, pois, somente assim, poderemos entender como uma questão de tamanha importância - a transmissão - teve o desenvolvimento do seu conhecimento marcado por marchas e contramarchas, idas e voltas, avanços e recuos.

Em resumo, a autora consegue trabalhar em torno da gênese do conceito de transmissão com três enredos, que, enquanto autônomos, são muitas vezes indistinguíveis: o científico, o ideológico-cultural e o das ações e intervenções sociais. Em um momento em que discutimos com intensidade o papel da saúde coletiva e da epidemiologia como campos científicos e como recursos para a promoção da saúde e a prevenção da doença, este livro traz novos elementos e possibilidades para a nossa reflexão. A autora, médica e epidemiologista, traz, na sua revisão histórica, um panorama do processo de constituição de alguns conceitos fundamentais. Ao fazer isto leva-nos a pensar o presente, o que a própria autora faz, utilizandose para tal do caso da epidemia de Aids. Contudo, este estímulo pode ser usado como referência para a reflexão de uma série infinita de outros problemas e questões. Ao mostrar os laços profundos entre ciência e ideologia na constituição de tais conceitos, ao mostrar as diferenças entre as intervenções geradas de duas perspectivas distintas - contagionistas versus miasmáticos - convida-nos a refletir sobre as bases científicas e as ideológicas que ancoram as diversas possibilidades de ações voltadas para a prevenção das doenças e para a promoção da saúde nos dias atuais.

O único reparo importante a ser feito ao texto foi assinalado pela própria autora - o fato de várias das fontes históricas terem sido consultadas em fontes secundárias, o que, se pode afetar o valor historiográfico da obra, a meu ver não diminui a sua capacidade de, ao reconstituir várias lacunas de uma história, provocar reflexões sobre o presente da saúde coletiva, da epidemiologia e da saúde das populações.

Maurício Lima Barreto

Instituto de Saúde Coletiva

Universidade Federal da Bahia

Salvador, BA

SAÚDE YANOMAMI: UM MANUAL ETNOLIN GÜÍSTICO. Bruce Albert \& Gale Goodwin Gomez, Belém: Museu Paraense Emílio Goeldi, 1997. 304 pp. Ilustrações.

ISBN 85-7098-049-3

Saúde Yanomami é um volume singular, possivelmente um dos únicos de seu gênero até o momento publicado no Brasil. Trata-se de um manual etnolingüístico cujo objetivo é transmitir para um público de não-especialistas em etnologia indígena (e Yanomami em particular) conceitos e, principalmente, informações lingüísticas da esfera da saúde. O livro foi elaborado no âmbito das atividades de saúde da Comissão Pró-Yanomami e, nas palavras de seus autores, concebido de modo que "pudesse cobrir a maioria das situações encontradas por profissionais de saúde na área Yanomami" (p. 23). Destina-se também a ser utilizado como recurso pedagógico no treinamento de equipes de saúde.

Um aspecto que merece ser mencionado diz respeito à gênese intelectual do volume. Foi redigido conjuntamente por Bruce Albert, conhecido etnólogo/ antropólogo da saúde e um dos principais especialistas na cultura Yanomami, e Gale Gomez, doutora em lingüística. É muito louvável a tentativa desses investigadores de buscar transmitir para um outro segmento profissional (profissionais de saúde envolvidos em atividades de assistência) informações coIhidas no contexto de pesquisas acadêmicas. Como bem coloca Alcida Ramos em sua apresentação, "é uma etnologia que não se limita a gerar conhecimentos antropológi cos por meio de descrições e análises que resultam da prolongada convivência com povos indígenas, mas vai mais longe. Ela coloca esses conhe cimentos diretamente a serviço dos povos estudados, ao seengajar ética epoliticamentecom o presenteefuturo desses povos". 
O livro é composto de duas partes principais: (1) uma introdução, na qual são abordados aspectos relacionados à cultura, sociedade, economia e saúde Yanomami, e (2) uma apresentação das informações lingüísticas. Esta segunda, por sua vez, subdivide-se em duas seções: uma lista de vocabulários e expressões básicas e uma outra de frases úteis (perguntas e respostas) no contexto de atendimentos.

Albert e Gomez optaram por apresentar a grande quantidade de informações por campos temáticos bem delimitados. Por exemplo, há uma lista de vocábulos e expressões relacionados a distúrbios respiratórios, gastrintestinais e odontológicos, e uma outra de sintomas de doenças específicas (febre amarela, hepatite, leishmaniose, malária, meningite, oncocercose etc.). Portanto, visando facilitar a utilização pelos profissionais de saúde, a lógica que estrutura o volume tem como referência o modelo biomédico ocidental de classificação, interpretação e tratamento de doenças. Sobre isso vale chamar a atenção para um ponto que, apresentado subliminarmente no texto (pp. 51-55), é de imensa importância prática. Ser capaz de se comunicar com relativa fluência verbal numa determinada língua não significa necessariamente que se compreendam os conceitos, práticas e visões de mundo dos falantes daquela língua. Ou seja, instrumentalizar os profissionais de saúde com expressões lingüísticas é uma etapa sumamente importante, ainda que não completamente suficiente, no processo de sanar as dificuldades de comunicação. Suponho que este ponto receba ampla atenção durante treinamento dos profissionais de saúde que irão atuar entre os Yanomami.

Há uma dimensão que gostaria de ter visto mais explorada no manual. Talvez reflexo da formação acadêmica de seus autores, há pouca ênfase na apresentação de uma panorama sanitário dos Yanomami, incluindo questões relativas à epidemiologia das doenças infecciosas e parasitárias. Não obstante, uma vez que o volume destina-se primordialmente a profissionais de saúde cujas atuações necessariamente envolvem um forte componente biomédico, seria informativo para este público específico um resgate mais matizado da relativamente extensa literatura biomédica acerca dos Yanomami.

SaúdeYanomami é um volume que, além de materializar uma necessária e bem-sucedida parceria entre academia e serviços de atenção à saúde de populações indígenas, sobressai-se pela relevância de sua proposta. Espero que o esforço dos autores se faça refletir positivamente sobre a dinâmica local de assistência à saúde dos Yanomami .

Ricardo Ventura Santos

Escola Nacional de Saúde Pública, Fundação Oswaldo Cruz e Museu Nacional, Universidade Federal do Rio de Janeiro Rio de Janeiro, RJ
A MORALIDADE DO ABORTO: SACRALIDADE DA VIDA E O NOVO PAPEL DA MULHER. Maurizio Mori. Brasília: Editora Unb, 1997.

This new book by Italian bioethicist Maurizio Mori is part of a new series published by the UNB entitled Health, Citizenship, and Bioethics. Translated by Roland Schramm, it arrives in Brazil as an academic resource and contribution to the public debate on abortion. This debate was consolidated in Brazil in 1989, when the National Council for Women's Rights brought the various Presidential candidates together in a televised nationwide debate in which they were asked to give their views on abortion. Since then, new data on the frequency of abortion in Brazil have confirmed that it is indeed a public health issue. New technological advances allowing for the prenatal identification of genetic defects currently raise new concerns and bring new actors to the debate.

Mori's proposal is to examine the various positions in the issue of abortion (defined as the voluntary interruption of pregnancy in the first trimester) on the supposition that "morality is above all a rational activity and a critical investigation". He thus emphasizes an analysis of the logical consistency of the various perspectives, particularly those of the Catholic Church.

But the discussion is not reduced to formal terms. Rather, it is set in the context of a brief history of abortion in the West from the time of the Greeks and Romans, who viewed the fetus as part of the woman's body, at a time when the existing knowledge of abortion was controlled by women themselves. The categorical prohibition of abortion came only with Christianity, justified by declaring it contrary to God's sovereignty. Mori describes some of the internal debates of the Catholic Church on the question of the fetus' status, and discusses the possible relationship between these debates and the development of medical obstetrics and embryology in the context of the liberal state and it's code of law, which also created a series of justifications for the prohibition of abortion. The history ends with the emergence of the women's movement and its public affirmation of the right to abortion.

Mori begins the second chapter by emphasizing that women's affirmation of the right to abortion has given the question its particular current shape. While earlier opponents referred to "violation of the matrimonial order" or to damages to the "state's higher interest", at this stage abortion is defined as "homicide". Pointing out possible relationships between "the influence of tradition and emergent demands", the author analyzes the coherence of the Catholic positions (with details regarding differences between the clergy and the ecclesiastic teachers), the "right to life" movement, the legalization position, and the liberalization position. Particularly important here is Mori's analysis regarding the question of the fetus' status in these various positions since, as he demonstrates, the position of the Catholic Church on this question is frequently misunderstood.

This part of the book ends with a number of considerations illustrating how the production of greater scientific information regarding the process of conception and development of a new being actually makes the very definition of what an abortion is more complex. 
In the second part of the book, Mori begins with a discussion of what a person is, this being a fundamental question for many who currently oppose abortion. Here, he is at his best as a philosopher and, despite having demanded the use of biological concepts at other points in the argument, and despite the fact that his argument here depends on information regarding cell division in the reproductive process, Mori is emphatic in his argument that "to speak of a biological definition of a person is a truecontradiction in terms". This discussion is of central importance for many questions in bio-ethics (including those concerned with new reproductive techniques). Even if we might question that "..it is to philosophy that we attribute the task of studying cultural phenomena" (unless we consider the social sciences as part of philosophy) we must agree that, even in the case of what we consider a person to be, "we cannot avoid. the 'arbitrariness' of a definition, as this is thelimit of all human discourse".

Continuing, Mori offers an analogy to the situation of a fetus, incapable of surviving autonomously, and discusses the limits to the right to life, when this depends on another person, or on the use of someone else's body. Mori argues that, even for those who consider the fetus to be a person (which is not his own position, or that of the Catholic Church, following his argument) ".the right to life does not imply the right to be all owed to remain connected to the body of someoneelse".

Since neither the status of the fetus nor the right to life rationally justify the prohibition of abortion according to the arguments Mori presents, he proceeds in the task of showing how the question of marriage and of the principle of life as sacred are the basis of the ban on abortion, most clearly (but not only) in the case of the Catholic Church. Here, he demon- strates the contradiction between the principle of life as sacred and the new view of a human being which presupposes that persons have the right to control their own selves. In this way he arrives, by other means, at the foundation of the political proposal of the women's movement: we are here confronted with a way of understanding gender equality and, consequently, women's social role: "If we admit the right to abortion, 'natural' bonds dissolve, and women are then free to construct their own destiny, the same as men do." The right to abortion questions traditional notions of maternity and procreation, of marriage and the family, and of women's role, "This is why the theme of abortion is so controversial and the cause of such profound social divisions".

Although Mori is coherent in frequently affirming that he does not intend to take sides regarding which principles are most correct, his conclusion is clearly favorable to those who argue, in the context of modern states, that abortion should be legalized or liberalized: "given the fact that in modern states, wherefreedom of religion prevails, legislation permitting abortion constitutes a question of civil or human rights".

Despite this fact, given the form of analysis of logical consistency of positions which substantiates the discussion, this book represents an intellectual (and, therefore, political) challenge for all positions, including those who have difficulty defining any position on such a difficult question. This is a very welcome book, focusing on a public health problem which is often treated as "a women's issue".

Karen Giffin

Departamento de Ciências Sociais Escola Nacional de Saúde Pública Fundação Oswaldo Cruz

Rio de Janeiro, RJ 